\title{
CHEMOSPHERE
}

\section{Frozen mitochondria as rapid water quality bioassay}

\author{
Alessandra Iero, Sabrina Manente *, Guido Perin, Marcantonio Bragadin \\ Department of Environmental Sciences, Dorsoduro 2137, Venezia 30123, Italy
}

Received 11 October 2002; accepted 19 November 2002

\begin{abstract}
A rapid and relatively low cost bioassay, usable in routine screening water test has been developed modifying the beef heart mitochondria test. In our experiments, mitochondria (FM22) were frozen at $-22{ }^{\circ} \mathrm{C}$, instead of $-80{ }^{\circ} \mathrm{C}$ (FM80), and their applicability and sensitivity was verified. The oxygen consumption was measured by a Clark electrode that was interfaced to a PC to collect test analysis data. Blank tests were carried out to verify the oxygen consumption linear fitting. Toxicity tests were performed using pure organic and inorganic compounds, such to verify the FM22 sensitivity. A piecewise regression, through an $\mathrm{Excel}^{\oplus}$ Macro, identified the break-point in the oxygen consumption and calculated the toxicity. The $\mathrm{IC}_{50} \mathrm{~s}$ of the tested compounds were calculated and ranged from 0.123 to $0.173 \mathrm{mg} / \mathrm{l}$ for heavy metals $(\mathrm{Cd}, \mathrm{Cr}, \mathrm{Cu}, \mathrm{Ni}, \mathrm{Pb}$ and $\mathrm{Zn}$ ) and from 0.572 to $10.545 \mathrm{mg} / \mathrm{l}$ for organics (benzene, DMSO, DDE, endrin, dichloromethane, chlorobenzene, 1,2-dichlorobenzene and 1,3-dichlorobenzene). Water effluent samples were then tested. The FM22 gave different toxic reactions to them. Water samples were characterised for heavy metals. The FM22 bioassay had a higher sensitivity than the FM80 and a high reproducibility in the toxicity test with pure compounds. The FM22 test was a good predictor of toxicity for water samples; the bioassay is easy, low cost and rapid, then usable for routine tests.
\end{abstract}

(c) 2003 Elsevier Science Ltd. All rights reserved.

Keywords: Toxicity test; Validation; Rapid screening; Effluents

\section{Introduction}

Organic and inorganic contaminants found in water result from domestic, industrial and agricultural wastes, accidental spillage or superficial runoff. Many of these substances eventually end up in the sediments and in surface and subsurface reservoirs, due to an increase of organic and inorganic contaminants in the biosphere, leading the problem of assessing the toxicity induced by these compounds.

Several methods have been proposed, using responses of whole organisms such as algae, fish and invertebrates,

\footnotetext{
*Corresponding author. Tel.: +39-041-2348634; fax: +39041-2578649.

E-mail address: manente@unive.it (S. Manente).
}

as extensively described in Cooney (1995) for freshwater systems. The problem, however, is not only strictly scientific, but also involves cost, resources and time. For example, fish require expensive testing facilities and long operational times are necessary for toxicity measurements.

Thus, more rapid and less expensive biosensors have been proposed (Bulich, 1979; Blondin et al., 1985, 1987; Yamano and Morita, 1993; Argese et al., 1995). Some biosensors use the responses of whole cells and of mitochondria (Knobeloch et al., 1990; Bragadin et al., 1991; Betterman et al., 1996; Riisberg et al., 1996; Palmeira and Madeira, 1997; Wenzel et al., 1997; Manente et al., 1999).

Mitochondria play a central bioenergetic role in the organisms. Since they produce ATP for the cells, any damage to their activity induced by toxic compounds may affect the entire organism (Chance and Williams, 
1955; Slater, 1967; Van Dam and Wiechmann, 1979; Mitchell, 1979; Hatefi, 1993). Therefore, mitochondria are good predictors for acute toxicity in solution as shown by Moreno and Madeira (1991), Shannon et al. (1991), Jeevaratnam and Vidya (1994), Bragadin et al. (1998), da Silva et al. (1998) and Bragadin et al. (1999a,b).

The method (FM80), using the response of $-80{ }^{\circ} \mathrm{C}$ frozen beef heart mitochondria has been proposed by one of the co-authors of this paper (Bragadin and Dell'Antone, 1994). Frozen mitochondria cannot produce ATP anymore, but the rate of ATP synthesis could be correlated by a stoichiometric ratio to the respiratory rate (that will be called "oxygen consumption" henceforth). The frozen mitochondria test, will eventually measure the inhibition in the respiratory rate induced by toxic compounds.

The goal of our research was to validate a test, similar to the FM80, having $-22{ }^{\circ} \mathrm{C}$ as frozen temperature for mitochondria. The test will be referred to as FM22 henceforth. This test will cut not only material costs, as mitochondria from the same preparation can be used for several months, but also, considerably, storage costs, since the $-22{ }^{\circ} \mathrm{C}$ is a less expensive freezer. Thus, considerations regarding the costs of storage and the rest of the laboratory equipment, and the time needed to carry out the experiments, led to consider this test suitable for fast screening and monitoring.

A series of experiments have been carried out using pure organic and inorganic compounds, in order to verify reproducibility and sensitivity of the method. Data were treated to calculate $\mathrm{IC}_{50}$ (inhibition concentration) of the compounds. Then, different water samples, mainly from industrial wastewater, were tested. The samples were characterised for metal contents by AAS trying to get, through chemical analysis, information on the potential risk.

\section{Material and methods}

Sucrose, tris- $\mathrm{HCl}$ and $\mathrm{Na}$-succinate for molecular biology were purchased from BDH. Pure reagents for atomic absorption were purchased from Sigma-Aldrich. Milliq water was used.

The mitochondria were prepared accordingly to Azzone et al. (1979) from bovine heart despite the classical hepatic source, due to two reasons: (a) possibility to obtain a higher quantity of mitochondrial proteins during a single procedure and (b) heart muscle mitochondria are considerably more resistant than liver ones to aging. Bovine heart mitochondria preparation steps can be resumed as follows. The bovine heart, once removed, is immediately placed in ice. It is essential to maintain the heart at $2-4^{\circ} \mathrm{C}$ through all steps. Once in the laboratory, the heart is carefully cleaned from fat and connective tissues and cut into little cubes. The cubes are then passed through a meat grinder $(4-5 \mathrm{~mm}$ plate holes, $250 \mathrm{rpm}$ ) and the minced meat is weighed (in order to reach pools of $\approx 500 \mathrm{~g}$ ). Each pool is then put in $0.25 \mathrm{M}$ sucrose, $5 \mathrm{mM}$ tris- $\mathrm{HCl}, 2 \mathrm{mM}$ EDTA-tris, $\mathrm{pH}$ 7.5 and shaken for $10 \mathrm{~min}$. The $\mathrm{pH}$ is eventually readjusted with $5 \mathrm{M}$ triethanolamine. Each pool, after being squeezed through a cheesecloth and freed from washing solution, was rearranged in $200 \mathrm{~g}$ pools, to which $500 \mathrm{ml}$ of solution A $(0.25 \mathrm{M}$ sucrose, $10 \mathrm{mM}$ tris- $\mathrm{HCl}, 1 \mathrm{mM}$ succinate-tris, $2 \mathrm{mM}$ EDTA-tris, $\mathrm{pH} 7.5$ ) is added and blended at $8000 \mathrm{rpm}$ for about $45 \mathrm{~s}, \mathrm{pH}$ readjusted to 7.5 with $5 \mathrm{M}$ triethanolamine. The homogenate is centrifugated (1300 rpm for $20 \mathrm{~min}$ ) and the supernatant solution is removed and filtered ( $\mathrm{pH}$ eventually readjusted to 7.5 with $5 \mathrm{M}$ triethanolamine) in order to obtain a suspension. The suspension is then centrifugated (15000 $\mathrm{rpm}$ for $15 \mathrm{~min}$ ) and the obtained supernatant is removed, while five times the volume of the pellet is resuspended adding solution $\mathrm{A}$. This mitochondrial suspension is homogenized in a glass-teflon homogenizer $(200 \mathrm{rpm})$ and then centrifugated again (15000 $\mathrm{rpm}$ for $15 \mathrm{~min})$. The final pellets are then resuspended in $0.75 \mathrm{M}$ sucrose, $10 \mathrm{mM}$ tris- $\mathrm{HCl}, \mathrm{pH}$ 7.5. Mitochondrial protein concentration was determined by the Lowry method (Lowry et al., 1951). Once prepared, the mitochondria were placed in $2.5 \mathrm{ml}$ Eppendorf vials and frozen at $-22{ }^{\circ} \mathrm{C}$ in our specific procedure.

The YSI 5331 Clark oxygen electrode was used. Blue Ribbon filter paper (retention $16 \mu \mathrm{m}$ ) was obtained by Schleicher \& Schuell GmbH. Heavy metals were determined by a Varian Spectr AA-250 Plus, bringing $\mathrm{pH}$ of samples to 2.0 by $\mathrm{HNO}_{3}$.

A scheme of the Pyrex vessel used for the toxicity test is shown in Fig. 1. The $2.5 \mathrm{ml}$ Pyrex vessel, closed by a teflon ${ }^{\circledR}$ cap, was thermostated at $25^{\circ} \mathrm{C}$; the solution was magnetically stirred. A very small hole in the vessel's cap allowed to insert the syringe needle for adding mitochondria, succinate and the testing solution.

\subsection{Bioassay methodology}

Mitochondria contained in the Eppendorf vials were quickly thawed out using $70{ }^{\circ} \mathrm{C}$ hot water for $30 \mathrm{~s}$ and then maintaining them at $0{ }^{\circ} \mathrm{C}$ in an ice-water bath while running the tests. For the test, thawed mitochondria were mixed by vortex and an aliquot, able to yield to a $0.1 \mathrm{mg}$ of mitochondrial protein in the $2.5 \mathrm{ml}$ of the vessel, was syringed and resuspended in $0.25 \mathrm{M}$ sucrose and $10 \mathrm{mM}$ tris- $\mathrm{HCl}$, at $\mathrm{pH}$ 7.4. No ATP was added; the bioassay was carried out in the state 4 of respiration (Lehninger, 1979), activated by adding succinate $1 \mathrm{mM}$.

Mitochondrial response to toxic substances was expressed as variation in the rate of oxygen consumption. 


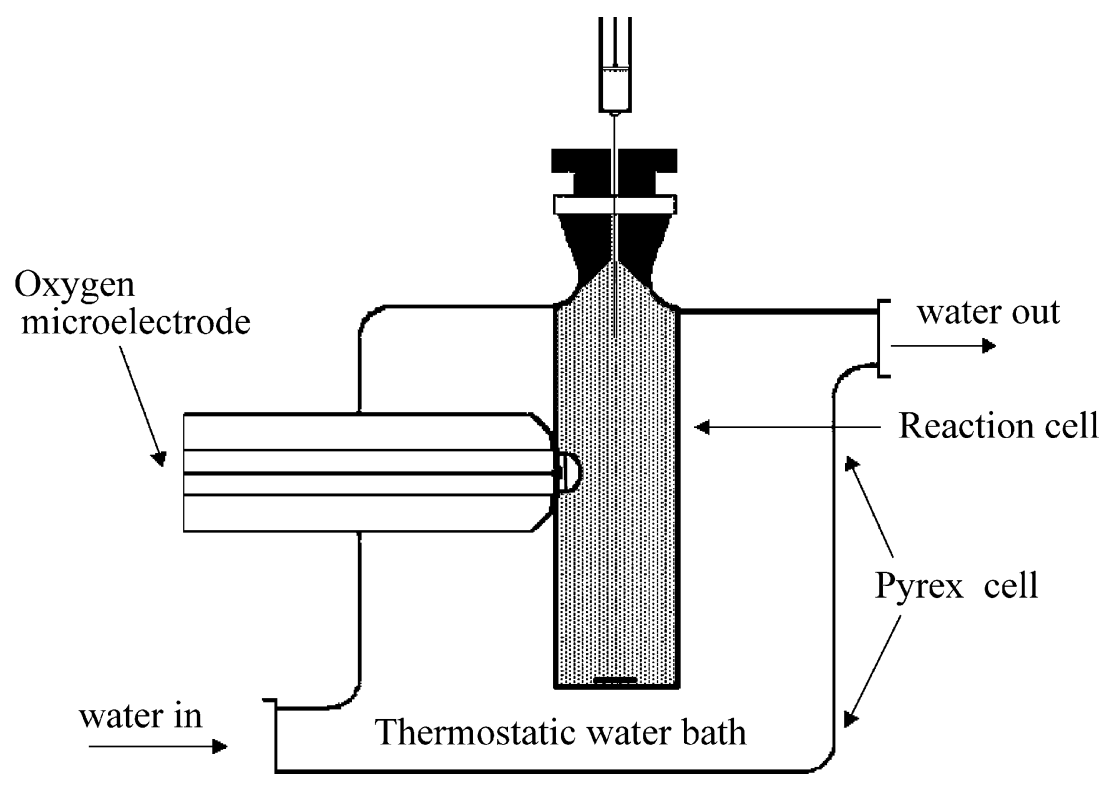

Fig. 1. The toxicity test vessel.

A Clark electrode polarographically monitored oxygen consumption (Lyons et al., 1974). It was interfaced to a PC by a PC multilab card "pcl-711s", that allowed to follow the oxygen trend in real time and to record the numerical data of each test. Each test was carried out for $20 \mathrm{~min}$, sampling one datum every second, thus getting 1200 numerical data for each test. The electrode output signal was amplified and conducted to the computer through the card. The multilab card is a low cost, multifunction PC plug-in I/O card turning the PC into a data acquisition system.

\subsection{Bioassay procedure}

A calibration step performing blank tests and tests on pure organic and inorganic compounds was carried out, in order to verify the FM22 reproducibility and their sensitivity.

During blank tests, only the medium, the mitochondria and the succinate were placed in the reaction vessel, to verify the linear fitting of the oxygen consumption rate. Toxicity tests started like a blank, with medium, succinate and mitochondria; after $5 \mathrm{~min}$ the toxicant to be tested was added in the vessel. An inhibition in the oxygen consumption induced by toxic compounds will eventually be expressed by a change in the slope of the oxygen trend. Therefore in the toxicity tests, the first part of the oxygen consumption trend represented the blank and was then compared to the second part, expressing the action of the toxicant. Pure compound toxicities were quantified comparing the slope before and after adding the compound. For each tested concentration, at least six replicates were run. Table 1 shows the concentration range used for each organic and inorganic tested pure compounds, the total number of replicates, the $\mathrm{IC}_{50}$ (expressed in $\mu \mathrm{g} / \mathrm{l}$ ) calculated by linear regression, and the standard deviations.

As numerical data of each test have been gathered, the toxicity was quantified by a statistical methodology that automatically identifies a "break-point" in the linear regression and quantifies the variation. The $\mathrm{IC}_{50}$ were calculated on the tested compounds (inhibition concentration $50 \%$, the concentration of the compound reducing the oxygen consumption by $50 \%$, as compared to its blank). Fig. 2 shows a typical inhibition trend. $Y$-axis has arbitrary units.

Once the bioassay sensitivity was verified using heavy metals and organic compounds, water samples from various effluents were tested. The water effluents were first filtered with Blue Ribbon filter paper and then 201 of sample was tested following the same methodology of pure compounds.

\subsection{Statistical methodology}

The linear fitting of $\mathrm{O}_{2}$ consumption rate was verified for $-22{ }^{\circ} \mathrm{C}$ frozen mitochondria: blank bioassay data were linearly regressed and the $R^{2}$ was used as indicator. Afterwards, toxicity tests were run. In each test the change in the oxygen consumption slope, due to toxicant action, was quantified by a "piecewise regression" (Quandt, 1958; Seber, 1989). An Excel $^{\circledR}$ macro was set up and applied the regression to the data-set. This allowed to identify the break-point, expression of toxicant action, and to quantify the slope variation. The "piecewise regression" finds the break-point (Beckman and 
Table 1

Each compound was screened within a wide range of concentration; each concentration was tested at least in six replicates

\begin{tabular}{|c|c|c|c|c|}
\hline Compound & Tested concentration range & $\begin{array}{l}\text { Total number } \\
\text { of replicates }\end{array}$ & $\begin{array}{l}\mathrm{IC}_{50} \\
(\mathrm{ppb})\end{array}$ & $\begin{array}{l}\text { Standard } \\
\text { deviation }\end{array}$ \\
\hline $\mathrm{Zn}^{2+}$ & $0.24<\operatorname{conc}(\mu \mathrm{g} / 1)<0.28$ & 18 & 0.173 & 0.080 \\
\hline $\mathrm{Cr}^{6+}$ & $0.20<\operatorname{conc}(\mu \mathrm{g} / 1)<0.32$ & 24 & 0.123 & 0.087 \\
\hline $\mathrm{Ni}^{2+}$ & $0.20<\operatorname{conc}(\mu \mathrm{g} / 1)<0.32$ & 24 & 0.125 & 0.056 \\
\hline $\mathrm{Cd}^{2+}$ & $0.20<$ conc $(\mu \mathrm{g} / 1)<0.40$ & 24 & 0.153 & 0.029 \\
\hline $\mathrm{Pb}^{2+}$ & $0.2<\operatorname{conc}(\mu \mathrm{g} / 1)<0.6$ & 24 & 0.143 & 0.080 \\
\hline $\mathrm{Cu}^{2+}$ & $0.008<\operatorname{conc}(\mu \mathrm{g} / \mathrm{l})<0.40$ & 48 & 0.128 & 0.152 \\
\hline Benzene & $0.35<$ conc $(\mu \mathrm{g} / 1)<7.02$ & 42 & 0.572 & 0.192 \\
\hline DMSO & $5.80<\operatorname{conc}(\mu \mathrm{g} / 1)<11.60$ & 24 & 4.515 & 0.221 \\
\hline DDE & $18.00<\operatorname{conc}(\mu \mathrm{g} / \mathrm{l})<90.10$ & 24 & 13.457 & 0.302 \\
\hline Endrin & $7.00<\operatorname{conc}(\mu \mathrm{g} / \mathrm{l})<10.00$ & 24 & 10.545 & 0.263 \\
\hline Dichloromethane & $1.00<\operatorname{conc}(\mu \mathrm{g} / 1)<3.20$ & 24 & 4.211 & 0.376 \\
\hline Chlorobenzene & $0.66<\operatorname{conc}(\mu \mathrm{g} / 1)<3.55$ & 36 & 0.743 & 0.077 \\
\hline 1,2-Dichlorobenzene & $0.52<\operatorname{conc}(\mu \mathrm{g} / 1)<1.41$ & 24 & 0.686 & 0.054 \\
\hline 1,3-Dichlorobenzene & $0.510<\operatorname{conc}(\mu \mathrm{g} / \mathrm{l})<1.150$ & 24 & 0.718 & 0.071 \\
\hline
\end{tabular}

A linear regression was applied to calculate $\mathrm{IC}_{50}$. More detailed explanation in the test.

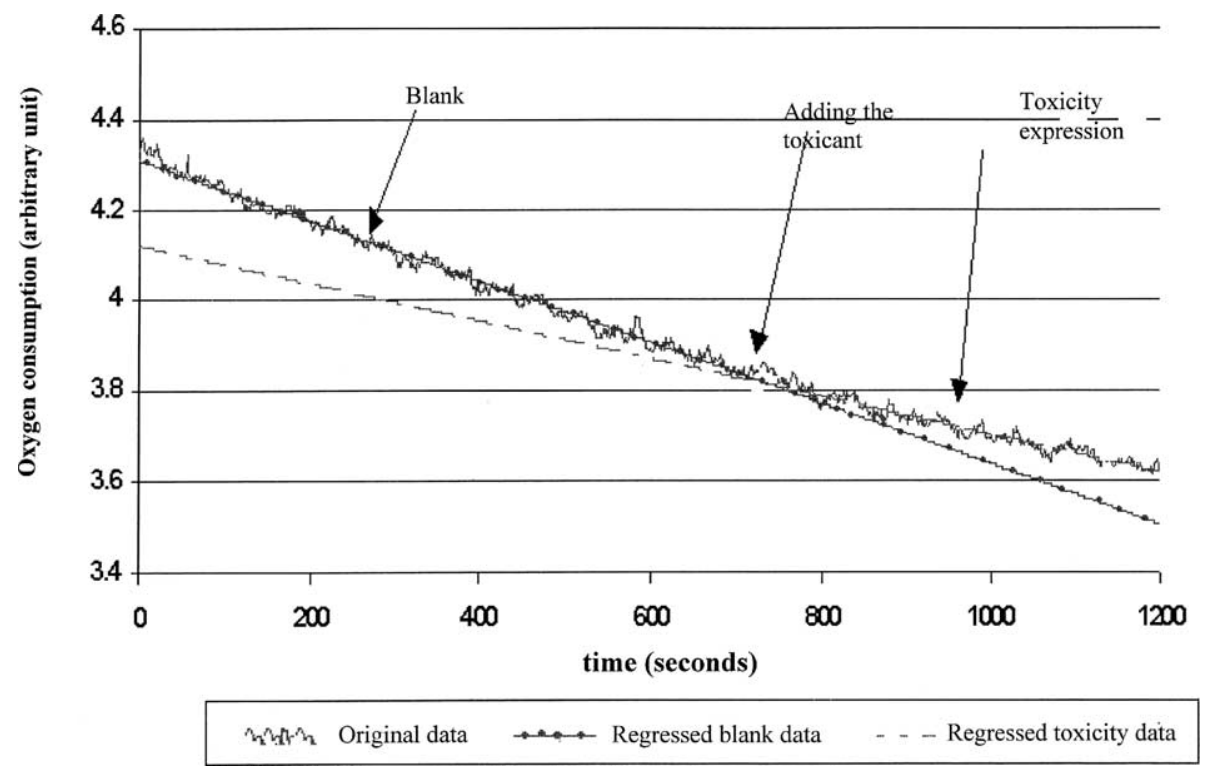

Fig. 2. A FM22 toxicity test output. The figure represents a typical direct output of the test (original data), and the data calculated through a linear regression after the piecewise regression identified the break-point (regressed blank data and regressed toxicity data). $Y$-axis is in arbitrary units.

Cook, 1979; Worsley, 1983) using a hypothesis test based on a $F$ statistic. Because the linear fitting had been verified for the bioassay, it was possible to apply this statistical procedure. Validation of the procedure was made through the large amount of numerical data gathered for each test (1200).

\subsection{Sampling methodology}

Surface water, industrial and municipal wastewaters were tested to verify the validity of the test method when applied to environmental samples. Diverse effluents were sampled, to evaluate the possibility of using the bioassay as a screening test for possible source of risk for the environment. Thirteen samples were taken in the vicinity of Venice (Italy) area and included three dumping sites (one municipal, sampled before and after the treatment, another municipal and one of special residues), three sewage treatments (one municipal, one industrial, one municipal and industrial, all sampled before and after the treatment) and three electroplating factories. Further 12 samples were taken in the Rovereto (Trento, Italy) area and included two surface water samples, one electroplating factory effluent, and nine different effluents 
from industrial plants (two food treatment, one pharmaceutical factory, one pulp mill and paper manufacture, two mechanical, two textile, one cleansing plants). Each sample was obtained on four hours sampling, to representatively average the effluent. Samplings were carried out following the standard methods for water and wastewater (Eaton et al., 1995).

\section{Results}

\subsection{Blank tests}

One hundred blank tests were performed and the $R^{2}$ was used as indicator of linearity. A descriptive statistic (Table 2) was obtained for the $R^{2}$ values that verified the blank linear fitting. The mean value of $R^{2}$ is very high and has a low standard deviation.

The preliminary assumption of a linear fitting for the oxygen consumption was confirmed from the results and it was possible to follow through with toxicity assays.

\subsection{Test calibration with pure compounds}

Toxicity tests have been run using pure heavy metals and organic compounds, usually found in environmental samples.

Table 2

Descriptive statistics for $R^{2}$ on blanks $(n=100)$

\begin{tabular}{ll}
\hline Mean & 0.9893 \\
Standard deviation & 0.0095 \\
Variance & $9.15 \mathrm{E}-05$ \\
Coefficient of variance & 0.9668 \\
\hline
\end{tabular}

Zinc (as $\mathrm{Zn}^{2+}$ ), chromium (as $\mathrm{Cr}^{6+}$ ), nickel (as $\mathrm{Ni}^{2+}$ ), cadmium (as $\mathrm{Cd}^{2+}$ ), lead (as $\mathrm{Pb}^{2+}$ ), copper (as $\mathrm{Cu}^{2+}$ ) have been tested in their ionic form, as they are well known for interfering with the normal functioning of mitochondria and cells. To prepare solutions we have used metal nitrate salts; indeed, it is known nitrates do not interfere with mitochondria respiration (Carpenedo and Floreani, 1989; Lodish et al., 1996) and the same kind of test performed with metal plus EDTA confirm this fact.

The non-chlorinated compounds benzene (polarity index $=0.3$ ) and dimetilsulfoxide (DMSO) (polarity index $=6.5$ ), the chlorinated solvents, dichloromethane, chlorobenzene, 1,2-dichlorobenzene, 1,3-dichlorobenzene, and two pesticides, DDE and endrin, have been tested.

All of the organic compounds are lipophilic, which may affect bioenergetic mitochondria functions, by alteration of the hydrophylic/hydrophobic interaction of the involved enzymes (Stolze and Nohl, 1994).

The $\mathrm{IC}_{50} \mathrm{~s}$ (in $\mu \mathrm{g} / \mathrm{l}$ ) calculation is performed (see Table 1) by linear regression among all tested concentrations (each one with at least six replicates). Standard deviation values are reported.

\subsection{Field water samples}

Toxicity results of the samples obtained from the two different industrialised zones are given in Fig. 3 and their legend in Table 3. Because they are complex environmental samples, their action on the oxygen consumption is indicated as inhibition percentage (\%) and scaled between 0 and 100 .

Metal content (Table 4) analysis shows high concentration of $\mathrm{Ni}^{2+}, \mathrm{Zn}^{2+}$ and $\mathrm{Cr}^{6+}$, as expected, in

\section{Samples toxicity tests}

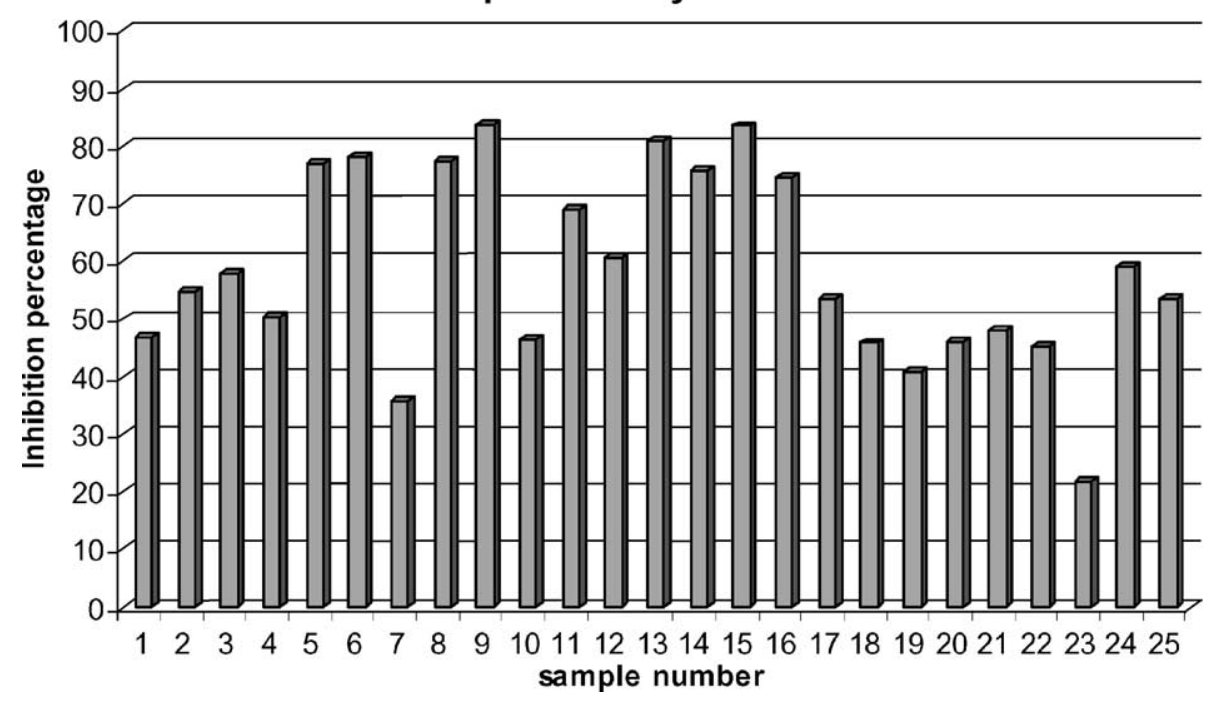

Fig. 3. Toxicity on FM22 bioassay of water samples. Results on inhibition percentage (\%). 
Table 3

Sources of samples

\begin{tabular}{|c|c|}
\hline Location number & Description \\
\hline 1 & Municipal dumping site (COVENOR, Ve) lecheate, treatment influent \\
\hline 2 & Municipal dumping site (COVENOR, Ve) treatment effluent \\
\hline 3 & Domestic sewage treatment (Caorle, Ve), influent to treatment \\
\hline 4 & Domestic sewage treatment (Caorle, Ve), effluent from treatment \\
\hline 5 & Dumping site (Ca' Rossa, Ve), lecheate \\
\hline 6 & Electroplating 1, influent to treatment \\
\hline 7 & Electroplating 1, effluent from treatment \\
\hline 8 & Electroplating 2, effluent from treatment \\
\hline 9 & Special residues dumpings (ECOVENETA, Ve), lecheate \\
\hline 10 & Industrial sewage (ENICHEM, Ve), influent to treatment \\
\hline 11 & Industrial sewage (ENICHEM, Ve), effluent from treatment \\
\hline 12 & Industrial/municipal sewage (Fusina, Ve), influent to treatment \\
\hline 13 & Industrial/municipal (Fusina, Ve), effluent to treatment \\
\hline 14 & Costa creek, Rovereto Tn, upstream of small industrial area \\
\hline 15 & Costa creek, Rovereto $\mathrm{Tn}$, downstream of small industrial area \\
\hline 16 & Textile factory (GETECA, Rovereto Tn) effluent \\
\hline 17 & Food treatment factory (ICARCONSERVE, Rovereto Tn), effluent \\
\hline 18 & Pharmaceutical factory (ROFERM, Rovereto Tn), effluent \\
\hline 19 & Dye factory (AQUASPACE, Rovereto Tn), effluent \\
\hline 20 & Mechanical activity (Microleghe Trentine, Rovereto Tn), effluent \\
\hline 21 & Mechanical activity (Meccanoptica, Rovereto Tn), effluent \\
\hline 22 & Cleaning activity (Pulisprint, Rovereto Tn), effluent \\
\hline 23 & Food treatment factory (Funghi Trentini, Rovereto Tn), effluent \\
\hline 24 & Electroplating (Galvanica Trentina, Rovereto Tn), effluent \\
\hline 25 & Pulp mill and paper manufacture (Aticarta, Rovereto Tn), effluent \\
\hline
\end{tabular}

Samples 1-13 are from an area in the vicinity of Venice; samples 14-25 are from an area in the vicinity of Rovereto (Trento).

samples $6,7,8$ collected in the vicinity of Venice from electroplating factories. However, in all samples heavy metals were detected, except for cadmium that was almost always below detection limit. In the Rovereto area samples (number 14-25), metals were mostly below detection limit, except for zinc that ranged between 3 and $86 \mu \mathrm{g} / \mathrm{l}$.

\section{Discussion}

The possibility of using the FM22 bioassay has been widely explored. Since no information on the activity of mitochondria frozen at $-22^{\circ} \mathrm{C}$ was available, blank tests were run first. The very high values of $R^{2}$ confirmed the oxygen consumption linear fitting. Afterwards, toxicity tests of pure compounds, based on the reduction of the respiratory rate, which had been quantified considering the slope change, were then run to check the method sensitivity.

A $-22{ }^{\circ} \mathrm{C}$ frozen bovine heart mitochondria batch can be stored before using it up to six months since it's preparation (data extrapolated from six preparations). Mitochondria from the same preparation and mitochondria from different preparations have shown variability in the oxygen consumption rate ranging between $5 \%$ and $15 \%$. However this variability does not represent an issue of concern as far as the slope variation, for toxicity calculations, is checked within each test run and then each mitochondria mini-pool works intrinsically.

Results from pure organic and inorganic compounds toxicity tests show a high sensitivity and a good reproducibility (except for $\mathrm{Cu}^{2+}$ ), highlighted by the large number of tests performed for each compound and by the low value of standard deviation. However, it can be pointed out how heavy metals $\mathrm{IC}_{50} \mathrm{~S}$ are all of the same order of magnitude, probably causing a similar effect on oxygen consumption of mitochondria, whereas organic compounds $\mathrm{IC}_{50} \mathrm{~s}$ are very variable.

The $\mathrm{IC}_{50}$ data show a very good sensitivity of the method as compared to the FM80 (Bragadin and Dell'Antone, 1994), as well as compared to other common bioassays (Pickering et al., 1989; RIVM, 1999) (Table 5). In fact, a comparison between FM80 EC 50 and $\mathrm{FM} 22 \mathrm{IC}_{50}$ shows the same order of magnitude for inhibition due to the heavy metals $\mathrm{Cd}, \mathrm{Pb}, \mathrm{Cu}, \mathrm{Zn}$, whereas $\mathrm{EC}_{50}$ of $\mathrm{Ni}$ in FM80 is one fold higher than in FM22 $\mathrm{IC}_{50}$. FM22 resulted more sensitive to organic compounds, except for DDE, than FM80. Comparing our method with other common bioassays (algal-bacterial, Daphnia magna, fish), we have to consider that various actions are implied. For organic compounds, the FM22 test shows greater sensitivity than the bacterial 
Table 4

Heavy metals determination

\begin{tabular}{|c|c|c|c|c|c|c|c|}
\hline & $\mathrm{Cd}$ & $\mathrm{Cr}$ & $\mathrm{Cu}$ & $\mathrm{Ni}$ & $\mathrm{Zn}$ & $\mathrm{Pb}^{\mathrm{a}}$ & $\mathrm{Fe}^{\mathrm{a}}$ \\
\hline 1 & $<0.01$ & 0.5 & 0.09 & 0.19 & 0.24 & 0.05 & 4.20 \\
\hline 2 & $<0.01$ & $<0.01$ & 0.01 & 0.03 & 0.86 & $<0.03$ & $<0.03$ \\
\hline 3 & $<0.01$ & $<0.01$ & $<0.01$ & 0.01 & 1.54 & $<0.03$ & 0.10 \\
\hline 4 & $<0.01$ & $<0.01$ & 0.01 & 0.02 & 0.18 & $<0.03$ & $<0.03$ \\
\hline 5 & $<0.01$ & 0.06 & 0.17 & 0.23 & 0.86 & $<0.03$ & 10.7 \\
\hline 6 & $<0.01$ & 20.6 & 1.40 & 4.72 & 1.51 & 0.105 & 4.93 \\
\hline 7 & 0.01 & 0.089 & $<0.01$ & 0.65 & 0.81 & $<0.03$ & 0.05 \\
\hline 8 & $<0.01$ & $<0.01$ & $<0.01$ & 0.10 & 0.71 & $<0.03$ & $<0.03$ \\
\hline 9 & $<0.01$ & 0.07 & 0.01 & 0.50 & 0.06 & $<0.03$ & 1.27 \\
\hline 10 & $<0.01$ & 0.02 & 0.01 & 0.02 & 0.37 & $<0.03$ & 0.08 \\
\hline 11 & $<0.01$ & $<0.01$ & $<0.01$ & 0.02 & 0.13 & $<0.03$ & 0.24 \\
\hline 12 & $<0.01$ & $<0.01$ & $<0.01$ & 0.03 & 0.05 & $<0.03$ & 0.06 \\
\hline 13 & $<0.01$ & 0.01 & $<0.01$ & 0.01 & 0.07 & $<0.03$ & 0.06 \\
\hline 14 & $<0.01$ & $<0.01$ & $<0.01$ & $<0.01$ & 0.04 & $<0.03$ & $<0.03$ \\
\hline 15 & $<0.01$ & $<0.01$ & $<0.01$ & $<0.01$ & 0.05 & $<0.03$ & $<0.03$ \\
\hline 16 & $<0.01$ & $<0.01$ & $<0.01$ & $<0.01$ & 0.03 & $<0.03$ & $<0.03$ \\
\hline 17 & $<0.01$ & $<0.01$ & $<0.01$ & $<0.01$ & 0.01 & $<0.03$ & $<0.03$ \\
\hline 18 & $<0.01$ & $<0.01$ & $<0.01$ & $<0.01$ & 0.08 & $<0.03$ & $<0.03$ \\
\hline 19 & $<0.01$ & $<0.01$ & 0.07 & 0.080 & 0.08 & $<0.03$ & $<0.03$ \\
\hline 20 & $<0.01$ & $<0.01$ & $<0.01$ & $<0.01$ & 0.01 & $<0.03$ & $<0.03$ \\
\hline 21 & $<0.01$ & $<0.01$ & $<0.01$ & $<0.01$ & 0.03 & $<0.03$ & $<0.03$ \\
\hline 22 & $<0.01$ & $<0.01$ & $<0.01$ & $<0.01$ & 0.03 & $<0.03$ & $<0.03$ \\
\hline 23 & $<0.01$ & $<0.01$ & $<0.01$ & $<0.01$ & 0.03 & $<0.03$ & $<0.03$ \\
\hline 24 & $<0.01$ & $<0.01$ & $<0.01$ & $<0.01$ & 0.03 & $<0.03$ & $<0.03$ \\
\hline 25 & $<0.01$ & $<0.01$ & $<0.01$ & $<0.01$ & 0.01 & $<0.03$ & $<0.03$ \\
\hline
\end{tabular}

Results are in $\mathrm{mg} / \mathrm{l} ; 0.01 \mathrm{mg} / \mathrm{l}$ detection limit.

${ }^{\mathrm{a}} 0.03 \mathrm{mg} / \mathrm{l}$ limit of detection.

and algal tests and D. magna (except for endrin), whereas results on heavy metals are quite different. Comparing to fish tests, the FM22 resulted more sensitive for heavy metals and organic compounds except for DDE and endrin. Something interesting has to be pointed out on DMSO: it resulted in high toxicity for FM22 and its harmfulness is quite well known. However, only toxicity data on FM80 and bacterial genotoxicity test have been found in the literature despite DMSO being a widely used solvent.

Although FM22 $\mathrm{IC}_{50}$ s were comparable with other tests, data on reproducibility of metals made us considering that they might require a longer time of actions in order to express an evident interaction with mitochondria. Thus, we are currently working on the development of a slightly different kind of test procedure, such to increase the time during which mitochondria and metals stay in contact. Indeed, previous results, from tests performed adding EDTA to bioassay medium, have shown no metal speciation alterations, i.e. resulting in a variable metal availability.

Results of the toxicity tests on samples confirmed the possibility of using this assay in a screening field analysis. The importance of bioassay is in its sensitivity when changes in sample characteristics occur. This fact emerged, especially, in testing samples from the same factory or plant, before and after any treatment occurred. Although, in the Venice area, samples 3-4 and 6-7 show less toxic action after treatment (samples 4 and 7), results from samples $1-2,10-11$ and 12-13 show the opposite, despite a decreasing in their metal contents. Similar results are obtained for the effluents sampled in the Rovereto area. In fact, samples 14 and 15 from the Coste Creek and sample 16 from the textile factory, show high toxicity for mitochondria, despite the few metals found; sample 19 presents a high quantity of metals but a relatively low toxic action. The complex mixture of the sample can thus have toxic results that may not always be detected by chemical analysis. Nevertheless considerations regarding reproducibility in the case of metal toxicity may be applied here too. Metal content, in these samples was quite low, thus toxicity action can be triggered by organics only.

Environmental samples are often difficult to analyse in an appropriate way. Their composition is unknown and a through screening would be very expensive and time consuming. Moreover, as compounds can synergistically/antagonistically act in the environmental systems, toxicity can even not be shown by the chemical composition. The aim of the bioassay is to synthesise the complex effect of a sample on a living organism or part of it. 
Table 5

Comparison of toxicity: $\mathrm{EC}_{50}$ for FM80, algae, bacteria, Daphnia, $\mathrm{LC}_{50}$ for fish

\begin{tabular}{|c|c|c|c|c|}
\hline & FM80: $\mathrm{EC}_{50}$ & $\begin{array}{l}\text { Bacterial-algal tests: } \\
\mathrm{EC}_{50}\end{array}$ & D. magna: $\mathrm{EC}_{50}$ & Fishes: $\mathrm{LC}_{50}$ \\
\hline $\mathrm{Zn}^{2+\mathrm{a}}$ & 0.08 & $0.1-0.5^{\mathrm{b}}$ & $0.025-0.1$ & 2.3 \\
\hline $\mathrm{Cr}^{6+\mathrm{a}}$ & & & $0.62^{\mathrm{c}}$ & \\
\hline $\mathrm{Ni}^{2+\mathrm{a}}$ & 9.10 & $0.36^{\mathrm{d}, \mathrm{e}}$ & & \\
\hline $\mathrm{Cd}^{2+\mathrm{a}}$ & 0.16 & $0.002-0.008^{\mathrm{f}}$ & & 11 \\
\hline $\mathrm{Pb}^{2+\mathrm{a}}$ & 0.08 & $2.7^{\mathrm{b}}$ & & \\
\hline $\mathrm{Cu}^{2+\mathrm{a}}$ & 0.09 & & $0.069^{\mathrm{e}}$ & 0.77 \\
\hline Benzene $^{g}$ & & $525^{\mathrm{h}}$ & 0.2 & 14 \\
\hline DMSO $^{g}$ & $3.16 \times 10^{4}$ & $0.008^{\mathrm{i}}$ & & \\
\hline $\mathrm{DDE}^{\mathrm{g}}$ & 0.79 & & & 0.24 \\
\hline Endring & & & 0.0042 & $0.21 \times 10^{-3}$ \\
\hline Dichloromethane $\mathrm{g}^{\mathrm{g}}$ & & $2292^{\mathrm{h}}$ & $220^{\mathrm{e}}$ & $99^{j}$ \\
\hline 1,3-Dichlorobenzene ${ }^{\mathrm{g}}$ & & $31^{\mathrm{b}}$ & $7.4^{\mathrm{e}}$ & 5 \\
\hline 1,2-Dichlorobenzene $\mathrm{g}^{\mathrm{g}}$ & 1.00 & $2.2^{\mathrm{f}}$ & 0.78 & 5.6 \\
\hline Chlorobenzene $\mathrm{g}^{\mathrm{g}}$ & 3.16 & $33^{\mathrm{f}}$ & 4.3 & 16 \\
\hline
\end{tabular}

Data in $\mathrm{mg} / \mathrm{l}$.

${ }^{\text {a }}$ Pickering et al. (1989).

${ }^{\mathrm{b}}$ Scenedesmus $q$.

${ }^{\mathrm{c}} \mathrm{IC}_{25}$.

${ }^{\mathrm{d}}$ Paramecium burs.

${ }^{\mathrm{e}} \mathrm{LC}_{50}$.

${ }^{\mathrm{f}}$ Selenastrum $c$.

${ }^{\mathrm{g}} \mathrm{RIVM}$ (1999).

${ }^{\mathrm{h}}$ Chlorella.

${ }^{\mathrm{i}}$ Saccharomyces $c .:$ positive to test of mutagenity induction.

${ }^{\mathrm{j}} \mathrm{EC}_{50}$.

Although mitochondria preparation is time consuming, their stableness under frozen storage permits their preparation only once every several months. Mitochondria from the same preparation were used up to six months not showing any change of behaviour and sensitivity. Results from calibration of this method confirmed a high sensitivity of the FM22 method, allowing the use of a $-22{ }^{\circ} \mathrm{C}$ storage temperature. The advantages of this technique are the inexpensiveness of common lab materials combined with the relatively short time of screening. In fact, it takes $20 \mathrm{~min}$ for the analysis and little time for the data treatment, then, results can be quickly obtained. The $-22{ }^{\circ} \mathrm{C}$ frozen mitochondria test is, thus, a good predictor of toxicity, easy to handle, fast and affordable.

\section{References}

Argese, E., Bettiol, C., Gheilli, A., Todeschini, R., Miana, P., 1995. Submitochontrial particles as toxicity biosensors of chlorophenols. Environ. Toxicol. Chem. 14, 363-368.

Azzone, G.F., Colonna, R., Ziche, B., 1979. Preparation of bovine heart mitochondria in high yield. Meth. Enzymol. $55,46-60$.

Beckman, R.J., Cook, R.D., 1979. Testing for two phase regressions. Technometrics 21, 65-69.
Betterman, A.D., Lazorchak, J.M., Dorofi, J.C., 1996. Profile of toxic response to sediments using whole animal and in vitro submitocondrial particle (SMP) assays. Environ. Toxicol. Chem. 15, 319-324.

Blondin, G.A., Knobeloch, L.M., Harkin, J.M., 1985. Bioassay of toxic substances in water. Wisc. Acad. Rev. 31, 31-33.

Blondin, G.A., Knobeloch, L.M., Read, H.W., Harkin, J.M., 1987. Mammalian mitochondrial as in vitro monitors of water quality. Bull. Environ. Contam. Toxicol. 38, 467-474.

Bragadin, M., Argese, E., Orsega, E.F., 1991. A simple "in vitro" method for selective detection of the presence of phenols in water using the mitochondrial membrane from rat liver. Environ. Tech. 12, 777-781.

Bragadin, M., Dell'Antone, P., 1994. A new in vitro test based on the response to toxic substances in solution of mitochondria from beef heart. Arch. Environ. Contam. Toxicol. 27, 410-414.

Bragadin, M., Manente, S., Iero, A., Perin, G., 1998. The respiratory chain of rat liver mitochondria as a probe for toxicological tests in water. Polish J. Environ. Stud. 7, 121123.

Bragadin, M., Marton, D., Iero, A., Manente, S., Perin, G., Rizzoli, V., Scutari, G., 1999a. A bioanalytical method for the monitoring of metal alkyls in solution. Anal. Biochem. 269, 420-423.

Bragadin, M., Perin, G., Iero, A., Manente, S., Rizzoli, V., Scutari, G., 1999b. An in vitro study on the toxic effects of nonylphenols (NP) in mitochondria. Chemosphere 38, 1997-2001. 
Bulich, A.A., 1979. Use of luminescent bacteria for determining toxicity in aquatic environments. In: Aquatic Toxicology Hazard Assessment. In: ASTM STP 667, pp. 98-106.

Carpenedo, F., Floreani, M., 1989. Farmacologia. Progetto Ed, Padova, Italy.

Chance, B., Williams, G.R., 1955. Respiratory enzymes in oxydative phosphorylation I. Kinetics of oxygen utilization. J. Biol. Chem. 217, 343-393.

Cooney, J.D., 1995. Freshwater tests. In: Rand, G.M. (Ed.), Fundamentals of Aquatic toxicology, second ed. Taylor \& Francis Publ, pp. 71-102.

da Silva, E.M., Soares, A.M.V.M., Moreno, A.J.M., 1998. The use of the mitochondrial transmembrane electric potential as an effective biosensor in ecotoxicological research. Chemosphere 36, 2375-2390.

Eaton, A.D., Clesceri, L.S., Greenberg, A.E., 1995. Standard Methods for the Examination of Water and Wastewater. APHA, Washington.

Hatefi, Y., 1993. ATP synteses in mitochondria. Eur. J. Biochem. 218, 759-767.

Jeevaratnam, K., Vidya, S., 1994. In vitro and in vivo effects of methyl isocyanate on rat brain mitochondrial respiration. Arch. Environ. Contam. Toxicol. 27, 272-275.

Knobeloch, L.M., Blondin, G.A., Read, H.W., Harki, J.M., 1990. Assessment of chemical toxicity using mammalian mitochondrial electron transport particles. Arch. Environ. Contam. Toxicol. 19, 828-835.

Lehninger, A.L., 1979. Biochemistry, second ed. Zanichelli, Bologna, Italy.

Lodish, H., Baltimore, D., Berk, A., Zipursky, S.L., Matsudaira, P., Darnell, J., 1996. Molecular Cell Biology, third ed. Scientific American Books Inc., NY, USA.

Lowry, O.H., Rosenbrough, N.J., Ferr, A.L., Randall, R.J., 1951. Protein measurements with the Folin phenol reagent. J. Biol. Chem. 193, 265-275.

Lyons, J.M., Raison, J.K., Kumamoto, J., 1974. Polarografic determination of phase change in mitochondrial membranes in response to temperature. Meth. Enzymol. 32, 258262.

Manente, S., Iero, A., Fabris, R., Perin, G., Rizzoli, V., Bragadin, M., 1999. A study of the toxic effects of six dibenzofuranes in mitochondria from rat liver. Polish $\mathbf{J}$. Environ. Stud. 8, 165-168.

Mitchell, P., 1979. Keilin's respiratory chain concept and its chemiosmotic consequences. Science 206, 1148-1159.

Moreno, A.J.M., Madeira, V.M.C., 1991. Mitochondrial bioenergetics as affected by DDT. Biochem. Biophys. Acta $1060,166-174$.

Palmeira, C.M., Madeira, V.M.C., 1997. Mercuric chloride toxicity in rat liver mitochondria and isolated hepatocytes. Environ. Toxicol. Pharmacol. 3, 229-235.
Pickering, Q., Carle, D.O., Pilli, A., Willingham, T., Lazorchak, J.M., 1989. Effects of pollution on freshwater organisms. J. Water Pollut. Control Fed. 61, 998-1042.

Quandt, R.E., 1958. The estimation of the parameters of a linear regression system obeying two separates regimes. J. Am. Stat. Assoc. 53, 873-880.

Riisberg, M., Bratlie, E., Stenersen, J., 1996. Comparison of the response of bacterial luminescence and mitochondrial respiration to the effluent of an oil refinery. Environ. Toxicol. Chem. 15, 501-502.

RIVM, 1999. Environmental Risk Limits in the Netherlands.

Seber, V., 1989. Non Linear Regression. John Wiley and Sons.

Shannon, R.D., Boardman, G.D., Dietrich, A.M., Bevan, D.R., 1991. Mitochondrial response to clorophenols as a shortterm toxicity assay. Environ. Toxicol. Chem. 10, 57-66.

Slater, E.C., 1967. Application of inhibitors and uncouplers for a study of oxidative phosphorilation. Meth. Enzymol. 10, $48-60$.

Stolze, K., Nohl, H., 1994. Effect of xenobiotics on the respiratory activity of rat mitochondria and the concomitant formation of superoxide radicals. Environ. Toxicol. Chem. 13, 499-502.

Van Dam, K., Wiechmann, A.H.C.A., 1979. Respiratory control and oxidative phosphorilation measurements in mitochondria. Meth. Enzymol. 55, 225-229.

Wenzel, A., Nendza, M., Hartmann, P., Kanne, R., 1997. Testbattery for the assessment of aquatic toxicity. Chemosphere 35, 307-322.

Worsley, K.J., 1983. Testing for two phase multiple regressions. Technometrics 25, 35-42.

Yamano, T., Morita, S., 1993. Effects of pesticides on isolated rat hepatocytes, mitochondria and microsomes. Arch. Environ. Contam. Toxicol. 25, 271-278.

Alessandra Iero received her Environmental Sciences degree in 1996 from Ca' Foscari, University of Venice, Italy. Actually she is continuing the research on mitochondria as indicator of toxicity and she is undertaking researches on freshwater quality.

Sabrina Manente received her Biological Sciences degree from University of Padova, Italy. She's currently a Ph.D. student at Ca' Foscari, University of Venice, focusing on heavy metals, biomarker and bioassay and on pollution problems.

Guido Perin is associated professor of ecotoxicology at the Department of Environmental Sciences of Ca' Foscari, University of Venice, Italy. His scientific interests include problems of pollution in water and sediments, activities on freshwater sites, on Venice lagoon and on Guanabara (Brasil) lagoon.

Marcantonio Bragadin is associated professor of toxicological chemistry at the Department of Environmental Sciences of Ca' Foscari, University of Venice, Italy. His scientific interests include in vitro measures of toxicity by xenobiotics. 